\title{
AT FACE VALUE : SHOULD A JURY WARNING ABOUT THE RISKS OF ASSESSING CREDIBILITY FROM DEMEANOUR BE MANDATORY IN CRIMINAL JURY TRIALS ?
}

Submitted for the LLB (Honours) Degree

Faculty of Law

Victoria University of Wellington

2014 


\begin{abstract}
In $E(C A 799 / 2012) v R$ [2013] NZCA 678 the Court of Appeal directly confronted the issue of whether demeanour warnings should be required in all criminal jury trials. Such a warning would alert a jury to the risks of using demeanour to assess credibility. While science has shown that demeanour is an unreliable tool for assessing credibility, the Court decided that a demeanour warning was not always required. As such, the law appears to be out of step with contemporary science. This article contrasts the traditional approach to the usefulness of demeanour evidence in criminal jury trials with a more modern understanding of its actual usefulness. Drawing on both social science and case authorities, this paper will critically evaluate the Court's approach to this issue. The conclusion is reached that a demeanour warning actually should be mandatory in all criminal jury trials.
\end{abstract}

Keywords for cataloguing: demeanour, criminal jury trials, credibility, Evidence Act 2006. 


\section{Contents}

Part I Introduction 4

Part II The problem relating to demeanour-based credibility assessments $\quad 7$

A The use of evidence of demeanour in New Zealand 7

B Social science research and the use of demeanour evidence 10

Part III The Court of Appeal's decision in E $v \mathbf{R}$

A The Court's review of relevant case authorities 13

B The Court's arguments against a demeanour warning 18

Part IV The usefulness of a demeanour warning 20

A Research on the efficacy of judicial directions 20

B Judicial discretion as to the importance of demeanour in a case 23

$\begin{array}{ll}\text { C General arguments against a demeanour warning } & 24\end{array}$

$\begin{array}{ll}\text { Part V Conclusions } & 27\end{array}$

Bibliography $\quad 29$ 
There's no one in the world who can look at a person and know that they are lying... there are a lot of bloody guilty people who can acquit themselves extremely well.... So is that what we are going to have? The best liar wins? ${ }^{1}$

\section{Introduction}

Historically, observation of a witness' demeanour while testifying was considered a reliable method of assessing their credibility. Judicial thought reflected this belief, and judges would regularly invite jurors to take a witness' demeanour into account when making such assessments. $^{2} \quad$ However, the consensus of current research casts serious doubts on the accuracy of this practice. Social science suggests that when people use demeanour to assess credibility, they operate at mere chance level. ${ }^{3}$ As Zuckerman and Roberts assert, most people would have greater success in spotting lies by tossing a coin, rather than relying on any assumed innate capability, to assess truthfulness. ${ }^{4}$

In 2013, the Court of Appeal was presented with an opportunity, in $E(C A 799 / 2012) v R$ ( $E v$ $R)$, to clarify the relative usefulness of demeanour, in assessing credibility. The Court heard three appeals, all of which raised the same question of law: whether a warning to the jury, about the risks of relying on demeanour to assess credibility, should be mandatory. ${ }^{5}$ In dismissing all three appeals the Court reached two conclusions: ${ }^{6}$

A warning about the risks of relying on the demeanour of a witness when assessing credibility is not invariably required.... [ and] ... two points should generally be conveyed to the jury in some form. First, the assessment of the credibility and reliability of a witness should be broadly based, taking into account the evidence as a whole and such of the factors we shortly describe as may be relevant to the case. Second, demeanour may properly be taken into

\footnotetext{
${ }^{1}$ Greg King, "Debate over the right to silence" ("Justice Hot Tub", Victoria University School of Law, Wellington, 20 July 2012).

${ }^{2}$ Lord Bingham "Assessing Contentious Eyewitness Evidence: Judicial View" in Anthony Heaton-Armstrong and others (eds) Witness Testimony, Psychological, Investigative and Evidential Perspectives (Oxford University Press, Oxford, 2006) at [18.12].

${ }^{3}$ Adrian Zuckerman and Paul Roberts Criminal Evidence ( $2^{\text {nd }}$ Ed, Oxford University Press, Oxford, 2010) at 299.

${ }^{4}$ At 299.

${ }^{5} E(C A 799 / 2012) \cup R$ [2013] NZCA 678 at [1].

${ }^{6} E(C A 799 / 2012) \cup R$ [2013], above $\mathrm{n} 5$, at [41].
} 
account but is best not considered in isolation. Rather, demeanour should be considered as one factor in the broader assessment.

Putting aside the inconsistency within these conclusions, they are problematic for two reasons. First, the Court's analysis downplays the problem itself, which is that demeanourbased credibility assessments are as likely to be wrong as they are correct. This problem is compounded by the fact that people generally have a completely inaccurate appreciation of their own ability to make such assessments. ${ }^{7}$ By failing to recognise the scope of the issue, the Court missed an opportunity to ensure that practice in jury trials conforms with state of knowledge of contemporary science.

Secondly, the Court ignores the vital purpose a demeanour warning could serve, in discouraging juries from relying on demeanour to assess credibility. For the purposes of this paper a demeanour warning refers to a warning to the jury that contains the following information:

- That demeanour is an unreliable tool for assessing credibility, due to the general inability of people to accurately make such assessments.

- There are significant risks in making demeanour-based credibility assessments.

- Instead of demeanour other indicia, such as consistency and plausibility, should be primarily used to assess credibility.

This is not to say that a demeanour warning would be completely effective. However, a mandatory demeanour warning is a preferable alternative to simply allowing juries to assess credibility from demeanour, without appreciating the risks involved. The better view is that since demeanour indicators are such an unreliable method of assessing credibility their influence should be minimised as much as possible. It follows then that a demeanour warning should always be given. This would improve the fact-finding process by encouraging jurors to assess credibility on a more reliable basis.

I will support this position through a three-pronged argument, in parts II, III and IV of this paper. Part II will examine the problems that demeanour poses, in terms of assessing credibility. It will provide some context, which will include the Court of Appeal's definition of demeanour in $E v R$, and some contemporary beliefs about the role of demeanour

\footnotetext{
${ }^{7}$ Andreas Kapardis Psychology and Law a Critical Introduction ( $3^{\text {rd }}$ Ed, Cambridge University Press, Melbourne) at 264.
} 
assessments in criminal jury trials. Next, it will investigate the actual usefulness of demeanour in assessing credibility, based on social science research. It will become clear that the Court's statement, that demeanour should still be part of the general credibility assessment, is not supported by current research.

Part III will examine the Court's analysis in $E v R$, including a review of relevant case authorities. It is submitted that these authorities support my argument, that a demeanour warning should be mandatory, rather than the Court's decision. I will also critically evaluate the reasoning which lead the Court to conclude that such warnings are not always necessary. This part will also deal with some additional sources that the Court drew upon to justify this conclusion, including Stanley v $R$ (Stanley), a New Zealand Law Commission report and the Evidence Act 2006 (the Act). ${ }^{8} \quad$ In particular, I will argue that the Act implicitly supports a mandatory demeanour warning.

Part IV will focus on how a jury warning would actually address the problem that demeanour poses for credibility assessments. This will include a brief exploration of jury research into the impact of judicial directions. I will argue that judicial discretion, in respect of demeanour warnings, is actually part of the problem. This is in contrast to the Court's assertion that such discretion should be unfettered. Finally, I will conclude that the better approach would have been to make a demeanour warning a mandatory part of a judge's directions to the jury in criminal trials.

${ }^{8}$ Stanley v R [2012] NZCA 462 ; Law Commission Evidence Law: Character and Credibility (NZLC PP 27, 1997). 


\section{The problem relating to demeanour-based credibility assessments}

\section{A The use of evidence of demeanour in New Zealand}

Demeanour has been described as "outward behaviour" or "bearing". 9 The Court in $E v R$ preferred Lord Bingham's characterisation of demeanour, although it further developed his Lordship's definition: ${ }^{10}$

We start our discussion by a consideration of what constitutes demeanour. Writing extra-judicially, Lord Bingham has described demeanour as:

“... [the witness's] conduct, manner, bearing, behaviour, delivery, inflexion; in short, anything which characterises [the witness's] mode of giving evidence but does not appear in a transcript of what [the witness] actually said." We add that demeanour also includes the personality or character of a witness. Given the breadth of what may be embraced by the concept of demeanour, we do not think it helpful to speak of "body language" as some traditional jury directions have done.

The Court's addition (in italics) was a problematic starting point for its discussion of demeanour, given that it is not strictly correct. While the Court included personality or character as part of demeanour, these are usually considered aspects of propensity evidence. What the Court described is essentially moral credibility or veracity, which is defined in the Act as the disposition of a person to refrain from lying, whether generally or in the proceeding. ${ }^{11}$ However, this is not what a jury is being asked to establish. Rather, a jury's task concerns an inquiry into probative credibility, which determines whether the witness is lying or telling the truth while giving evidence. This does not involve character, but the accuracy and reliability of the witness' statements. ${ }^{12}$

Of greater concern was the Court's assertion that demeanour should still be part of the overall credibility assessment, although it did acknowledge that demeanour in isolation was not a good indicator of credibility. ${ }^{13}$ This suggests that the Court believed that while demeanour might not be useful by itself when it is weighed alongside other factors, such as consistency,

\footnotetext{
${ }^{9}$ Catherine Soanes Angus Stevenson (eds) Oxford Concise English Dictionary ( $11^{\text {th }}$ Ed, Oxford University Press, New York, 2008) at 380.

${ }^{10} E(C A 799 / 2012) v R$ [2013] above n 5, at [24]; Lord Bingham, above n 2 , at [18.13-18.20].

${ }^{11}$ Evidence Act 2006, s 37(5).

12 Zuckerman and Roberts, above n 3, at 347.

${ }^{13} E(C A 799 / 2012) \cup R$ [2013], above n 5, at [43].
} 
it may be useful in assessing credibility. I submit that this is a flawed premise. The addition of other factors is not going to change the nature of demeanour indicators so that they suddenly become a more reliable guide to credibility. If anything, the reverse is true. As research has shown, demeanour indicators are as likely to give jurors incorrect clues as to a witness' credibility, as they are correct ones. ${ }^{14}$ Thus, demeanour is likely to confuse the overall credibility assessment, as at least half of the time it will be at odds with the more reliable credibility indicators.

The Court's insistence on keeping demeanour as part of the credibility assessment exercise shows a disconnection between the scientific understanding that demeanour is not an accurate tool for assessing credibility, and the justice system's preference for live testimony. Although it has been suggested that there is no presumption that evidence must be presented in this way, the Evidence Act 2006 expressly provides that the ordinary method of giving evidence is via a witness testifying in person before the judge and/or jury. ${ }^{15}$ According to Zuckerman and Roberts this inclination towards viva voce evidence seems based on the assumption that demeanour is a reliable guide to veracity. ${ }^{16}$

Social science strongly indicates that this assumption is incorrect, as the next section of this paper will discuss in greater detail. Regardless, the Act's provisions ensure that usually a jury will hear a witness' evidence in person. Thus, a witness' demeanour will generally be on display while they testify and has the potential to confuse the jurors' credibility assessment, with potentially misleading cues. For example, a witness' demeanour while presenting evidence often determines how convincingly the content of that evidence is delivered. ${ }^{17}$ Research has shown that speakers who exude confidence are more likely to be believed than nervous ones. ${ }^{18}$ This is problematic, given that confidence and nervousness may have no relation to whether the witness is telling the truth. ${ }^{19}$

\footnotetext{
${ }^{14}$ Zuckerman and Roberts, above n 3, at 300.

15 Elisabeth McDonald Principles of Evidence in Criminal Cases ( Brookers, Wellington, 2012) at 86.

16 Zuckerman and Roberts, above n 3, at 300.

17 Zuckerman and Roberts, above n 3, at 299.

${ }^{18}$ Robert Fisher "Can we tell when people are lying? " (Paper presented to AMINZ conference, Auckland, 25 July 2013) at 5 ; Hazel Genn “Assessing Credibility” (2011) 11 Tribunals Journal at 2.

19 Genn "Assessing Credibility", above n 18, at 2.
} 
Even when a witness testifies in an alternative way demeanour is implicitly in issue. ${ }^{20}$ In such circumstances, the Act requires the judge to direct the jury not to draw any adverse inferences against the defendant. ${ }^{21}$ The requirement for a direction implies that juries will not automatically treat evidence from a screened or pre-recorded witness the same way they would a witness in-person. Similarly, the Courts (Remote Participation) Act 2010 provides for witness' testimony to be delivered via audio-visual link, when the witness cannot be physically present in the courtroom. ${ }^{22}$ When deciding whether to allow a witness to present evidence from a remote location, a judge must consider the potential impact on the parties' ability to assess the witness' credibility. ${ }^{23}$ This suggests that Parliament believed there was some particular advantage to hearing testimony in person. The implication, of Parliament's drafting in both enactments, is that there is a persistent notion that demeanour can be useful in assessing credibility, even at the legislative level.

In some cases the inability to observe a witness' demeanour has given rise to arguments that this breaches the defendant's rights to confront their accuser and conduct a full defence. 24 In particular, it has been argued that a witness' demeanour must be available for the jury's consideration during cross-examination. ${ }^{25}$ Such arguments rely on the New Zealand Bill of Rights Act 1990, which specifically provides for a defendant's right to present a defence and examine the prosecution's witnesses. ${ }^{26}$ In Police $v$ Razamjoo (Razamjoo), a case of fraud, two female Muslim witnesses were required to remove their burqa while giving evidence. ${ }^{27}$ However, they were allowed to testify from behind a screen, so their faces could only be seen by the Judge, counsel and female court staff. The Court felt this was an appropriate balance between the witnesses' religious rights and the defendant's fair trial entitlements. ${ }^{28}$ Similar arguments have been raised in other jurisdictions, with troubling implications for rape and sexual assault complainants. ${ }^{29}$

\footnotetext{
${ }^{20}$ Evidence Act 2006, s 105.

${ }^{21}$ Section 123.

22 Courts (Remote Participation) Act 2010, s 7.

${ }^{23}$ Section 5(c)(i).

${ }^{24}$ Richard Mahoney and others The Evidence Act 2006 Act and Analysis ( $3^{\text {rd }}$ ed, Brookers, Wellington, 2014) at 466.

25 At 377.

${ }^{26}$ New Zealand Bill of Rights Act 1990, s 25(e)(f).

${ }^{27}$ Police v Razamjoo [2005] DCR 408.

${ }^{28}$ Police v Razamjoo [2005], above $\mathrm{n}$ 27, at [22].

${ }^{29}$ See $R v S(N)$ [2012] 3 S.C.R. 726 at [99]-[109] per Abella J dissenting.
} 
The Razamjoo decision appears to reinforce the view that it is important for a jury to be able to see a witness' demeanour. The pervasiveness of this belief was also apparent in a recent decision of Hon Judith Collins, Minister of Justice ("The Minister"). The Minister sought Cabinet's approval to rescind a previous decision relating to a required demeanour warning for child witnesses giving evidence in an alternative way. ${ }^{30}$ The original permission was for a required judicial warning to prevent jurors drawing inferences from a child witness' demeanour, particularly if that demeanour displayed a lack of distress. ${ }^{31}$ However, the Minister stated that demeanour could be a relevant consideration for the jury in determining credibility. ${ }^{32}$ She reasoned that if inferences could not be drawn from demeanour, evidence would not need to be given in person. ${ }^{33}$ The Minister is correct that demeanour observation of a witness' testimony sometimes allows for the drawing of correct inferences. However, as research has shown, those inferences are equally likely to be incorrect.

\section{B Social science research and the use of demeanour evidence}

Social science played only a minor role in the Court of Appeal's reasoning in $E v R$. Although the Court acknowledged a number of authorities the appellant cited, it confined them to a single footnote. ${ }^{34}$ The Court also acknowledged Professor Paul Ekman's assertion that "few people do better than chance when judging whether someone is lying or truthful." 35 However, it still based its conclusions primarily on judicial rather than scientific thought. In contrast, other courts have shown less reluctance to make use of science in reaching their conclusions. The Court of Appeal in Rv Munro (Munro) used several articles to supplement its assertions on the perceived difficulties with jurors' credibility assessments. ${ }^{36}$ In $E$ (CA113/09) $\vee R$ (No 3) the Court of Appeal utilised Aldert Vrij's work in respect of lie detection, to support its conclusion that a witness' credibility could be assessed from a prerecorded video, without first-hand observation of their demeanour. ${ }^{37}$

\footnotetext{
${ }^{30}$ Judith Collins "Amendments to the Evidence Act 2006" (12 November 2013) CAB 100/2008/1 at [43-46].

31 At [44].

32 At [45].

33 At [45].

${ }^{34} E(C A 799 / 2012)$ v $R$ [2013], above n 5, at [21].

${ }^{35}$ E (CA799/2012) v R, above n 5, at [31]; Paul Ekman Telling Lies (Berkley Books, New York, 1986).

${ }^{36}$ R v Munro [2007] NZCA 510 at [79-81]; Marcus Stone " Instant lie detection? Demeanour and credibility in criminal trials" Crim. L.R. $1991821-830$.

${ }^{37} E(C A 113 / 09)$ v $R(N o$ 3) [2010] NZCA 544 at [75], [82],[86] and [88].
} 
By making only a token acknowledgment of contemporary social science I suggest that the Court in $E v R$ missed an important step. While research alone could not have been determinative of the legal issue, at the very least it could have aided the Court in reaching a conclusion on the practical issues surrounding demeanour - as the Courts in $E(C A 113 / 09) v$ $R$ (No 3) and Munro appear to have done. It is not suggested that it would have been appropriate for the Court of Appeal to commence an intensive review and then decide solely on the basis of research findings. But, by concentrating on judicial statements and giving little attention to the research perspective, the Court virtually ignores the underlying scientific basis upon which the validity of those judicial statements rests. As such, I argue that the Court should have based its views on contemporary social science research.

Had it done so, the Court would have gained an appreciation of the two highly problematic elements in demeanour-based credibility assessments. First, demeanour itself is an unreliable tool for assessing credibility. As previously stated, research has shown that when people use demeanour indicators to assess another person's credibility, they operate at mere chance level, whether they are professionals or laypeople. ${ }^{38}$ Fifty years of research into lie detection has shown that generally a person's probability of spotting a lie, based on observation of behaviour and listening to speech, is about 54 per cent. ${ }^{39}$

This general deficiency in lie detection arises in part from people's reliance on the wrong cues, particularly gaze aversion and nervousness, to indicate dishonesty. ${ }^{40}$ Generally held beliefs about which demeanour cues signal deception are often fundamentally wrong. ${ }^{41}$ Ian Coyle described a jury's assessments of credibility being based partly upon "worthless though pervasive behavioural stereotypes." 42 Coyle asserted that a very significant proportion of both laypersons' and professionals' beliefs about non-verbal and verbal cues to deception have been repeatedly shown to be incorrect. ${ }^{43}$ Similarly, experimentation has

\footnotetext{
${ }^{38}$ Elisabeth McDonald and Yvette Tinsley "Use of Alternative Ways of Giving Evidence by Vulnerable Witnesses: Current Proposals, Issues and Challenge" 42 VUWLR 705 at 20.

${ }^{39}$ Aldert Vrij, Par Anders Granhag, Samantha Mann and Sharon Leal, "Outsmarting the Liars: Toward a Cognitive Lie Detection Approach” (2011) Current Directions in Psychological Science 20 (1) 28 at 28.

${ }^{40}$ Aldert Vrij, Par Anders Granhag, Stephen Porter “Pitfalls and Opportunities in Nonverbal and Verbal Lie Detection" (2010) Psychological Studies in the Public Interest 000(00) at 8 and 10.

${ }^{41}$ Kapardis, above n 7, at 266.

${ }^{42}$ Ian R Coyle "How Do Decision Makers Decide When Witnesses Are Telling The Truth And What Can Be Done To Improve Their Accuracy In Making Assessments Of Witness Credibility?” ( Report to The Criminal Lawyers Association of Australia and New Zealand, 3 April 2013) at 8.

${ }^{43}$ Coyle, above n 42 , at 3 and 8.
} 
demonstrated that the ordinary person's ability to determine truthfulness based on observing these cues, is virtually non-existent. ${ }^{44}$

While demeanour can be a useful tool for interpreting ordinary behaviour under normal circumstances, in the artificial environment of a courtroom those norms do not apply. 45 Reliance on demeanour leaves the jury open to two types of potential error: mistakenly believing a liar and mistakenly disbelieving a truthful witness. ${ }^{46}$ The confident liar is able to exhibit physiological signs that would normally be associated with truthfulness whereas a truthful witness, whose psychological make-up includes a fear of being disbelieved, will exhibit discomfort and anxiety under examination. ${ }^{47}$ It has been suggested that repeat offenders are likely to give evidence with increased confidence, and are thus more likely to be believed. ${ }^{48}$

These incorrect beliefs about demeanour cues have also been discussed in relation to rape complainants. $^{49}$ Demeanour based credibility assessments are particularly unjust to such complainants, because of reliance upon myths about the way they should react. ${ }^{50}$ As such, a truthful complainant who does not display demeanour consistent with commonly held beliefs about rape victims may find that jurors, incorrectly, find them less credible. While it is commonly perceived that high levels of emotion are associated with credibility for rape victims, neither a highly-emotional nor a seemingly emotionless appearance have any relation to truthfulness. ${ }^{51}$

The second problematic aspect of demeanour-based credibility assessments is that people's perceptions of their ability to make such evaluations are generally incorrect. Even police and corrections officers, who routinely deal with criminals, have no greater ability to discern truthfulness than a layperson. ${ }^{52}$ Essentially, people are as likely to be wrong as they are right, while at the same time believing they are making correct credibility assessments.

\footnotetext{
${ }^{44}$ Olin Guy Wellborn "Demeanour” (1991) 76 Cornell L Rev 1075 at 12.

45 Stone, above $\mathrm{n} 31$, at 4.

46 Genn, above n 18, at 3 ; Stone, above n 31, at 4; Ekman, above n 30.

47 Genn, above $\mathrm{n} 18$, at 4.

48 Fisher, above n 18, at 5.

49 McDonald and Tinsley, above n 36.

${ }^{50}$ Natasha Bakht What's in a Face ? "Demeanour Evidence in the Sexual Assault Context" in Elisabeth A. Sheehy (ed) Sexual Assault in Canada (University of Ottawa Press, 2012) at 600.

${ }^{51}$ McDonald and Tinsley, above n 33, at 20 .

${ }^{52}$ Kapardis, above n 7, at 265.
} 
Zuckerman and Roberts characterise this as a "double whammy" to the tradition of live oral testimony. 53

The clear message of contemporary research can be summed up in the following statement, by former High Court Judge Robert Fisher QC: ${ }^{54}$

The overwhelming conclusion is that demeanour is not a useful guide to veracity. There are no observational advantages when assessing the honesty of a witness' evidence... Those who think they are capable of assessing veracity through demeanour are mistaken.

If the conclusions of social science research are to be accepted, then it appears that the best approach would be to minimise the impact of demeanour on credibility assessments, as much as possible. The Court of Appeal in $E v R$ concluded that traditional directions which emphasised the usefulness of demeanour in assessing credibility, needed to be modified. ${ }^{55}$ Although this represents progress from the previous position, I submit that this is still insufficient to bring the law into step with science. Rather, juries should always be warned against using demeanour to make such assessments. At the very least, jurors should be expressly told that if they place reliance on demeanour to ascertain a witness' credibility they have a one in two chance of making an incorrect determination.

\section{The Court of Appeal's decision in $E v R$}

\section{A The Court's review of relevant case authorities}

As discussed above the Court in $E v R$ placed very little reliance on social science. Instead it preferred judicial views on demeanour's usefulness, which it drew from relevant cases and extra-judicial writing. However, I submit that the Court's conclusions are actually at variance with what these sources say, regarding the problematic nature of demeanour-based credibility assessments. The Court cited Lord Devlin, who suggested that any advantages to hearing testimony first-hand in order to assess truthfulness were overrated. ${ }^{56}$ Similarly, Justice MacKenna suggested that as a judge he relied on demeanour cues as little as possible in order

\footnotetext{
53 Zuckerman and Roberts, above n 3, at 300.

${ }^{54}$ Fisher, above $\mathrm{n} 18$, at 5.

${ }^{55} E(C A 799 / 2012) \cup R$ [2013], above n 5, at [42].

${ }^{56} E(C A 799 / 2012) v R$, above $\mathrm{n} 6$ at [26]; Patrick Devlin The Judge (Oxford University Press, Oxford, 1979) at 63.
} 
to determine fact. ${ }^{57}$ Even stronger statements were made by Lord Bingham, from whom the Court drew its definition of demeanour. His Lordship asserted that, "To rely on demeanour is in most cases to attach importance to deviations from a norm when there is in truth no norm."58 All of these statements clearly question whether demeanour has any use in assessing credibility. Yet the Court of Appeal did not reach the same conclusion.

The Court also cited a number of cases which discussed "the demeanour issue." 59 When read as a whole, these authorities also seemed to strongly question demeanour's usefulness in assessing credibility. In Fox v Percy (Fox) it was suggested that contemporary judges are now much more aware of the doubts that science casts on people's ability to assess credibility from demeanour cues. ${ }^{60}$ In Munro a full court of the Court of Appeal challenged the ability of juries to determine credibility from demeanour observation. ${ }^{61}$ The Court, in Munro, also specifically discussed credibility and demeanour within the context of research, and expressly referred to Marcus Stone's finding that visual cues which might traditionally be associated with honesty are not necessarily indicative of truthfulness. ${ }^{62}$ That Court also agreed that the artificial environment of the courtroom hinders most jurors' assessment of credibility. ${ }^{63}$ The Court, in Munro, also accepted that confident speakers are more likely to be believed, regardless of whether they are actually telling the truth. ${ }^{64}$

However, the Court in $E v R$ cited Munro for the statement that, "tone of voice, pauses, gestures and facial expression could all assist in conveying meaning" as if to suggest that Munro is an authority which supports the use of demeanour in assessing credibility. ${ }^{65}$ It is true that in Munro the Court did suggest there were advantages in hearing or seeing witnesses directly, but this was said in the context of contrasting the positions of a judge at first instance with that of an appellate court. ${ }^{66}$ Also these remarks must be kept in context with other statements made in Munro, concerning the unhelpfulness of demeanour in assessing credibility, and its direct references to the research supporting that view. The Court in $E \vee R$ also appears to contrast Munro with Fox, as though the two cases stood for

${ }^{57} E$ (CA799/2012) $v R$, above n 5, at [27]; Brian MacKenna "Discretion" (1974) IX (new series) The Irish Jurist at 10.

${ }^{58} E(C A 799 / 2012) v R$, above $\mathrm{n} 5$, at [24]; Lord Bingham, above n 2, at [18.18].

${ }^{59} E(C A 799 / 2012) v R$, above n 5, at [24]; At [30]

${ }^{60}$ At [30]; Fox v Percy (2003) 214 CLR 118 at [31].

${ }^{61} R$ v Munro [2007], above $\mathrm{n} 31$, [84].

${ }^{62} R v$ Munro [2007] above $\mathrm{n} 31$, at [79].

${ }^{63} E(C A 799 / 2012) \vee R$, above n 5, at [31]; $R$ v Munro [2007], above $\mathrm{n} 31$, at [79].

${ }^{64} E(C A 799 / 2012) \vee R$, above $\mathrm{n} 5$, at [31]; $R$ v Munro [2007], above $\mathrm{n} 31$, at [79-80];

${ }^{65} R$ v Munro [2007] above $\mathrm{n} 31$, at [73].

${ }^{66}$ At [74]. 
different propositions. This is not so. In Munro the Court not only cited Fox with approval but the statements, regarding the limitations of demeanour-based credibility assessments are congruous between the two cases. ${ }^{67}$

Another relevant authority, the Court of Appeal's decision in $E(C A 113 / 09) v R(N o 3)$, also stressed the risks inherent in relying on demeanour to assess credibility, and expressly cited Vrij's work as evidence of those risks. ${ }^{68}$ That Court approached questions regarding demeanour from a slightly different angle i.e. whether hearing evidence first-hand gives any advantage, compared to an appellate court's usual reliance on transcripts. ${ }^{69}$ However, that Court still made a clear statement about the risky nature of demeanour-based credibility assessments. ${ }^{70}$

A similar statement was made in Sateki $v R$ (Sateki). In that case the Court of Appeal commented that demeanour was a "notoriously unreliable means of assessing credibility". ${ }^{71}$ This seems to affirm the dangers of reliance upon demeanour. The Court of Appeal in $E v R$ felt that "notoriously unreliable" was too strong a characterisation, preferring to acknowledge a degree of risk in relying on demeanour alone. This downplaying of the risks seems at odds with the Court's earlier acknowledgment of the work of Paul Ekman and Lord Bingham. Both of those authors' comments seem to support the argument that "notoriously unreliable" is actually an accurate characterisation.

In the case of $S(C A 749 / 2012) \vee R(S \vee R)$, the Court of Appeal took a similar approach to Sateki stating that there were "well-recognised dangers" in assessing credibility through demeanour. ${ }^{72}$ This appears to be a clear acknowledgement of the problem. The Court in $E v$ $R$ mentioned this point almost in passing, which is consistent with its overall approach to the case authorities. In my view the Court failed to acknowledge the cumulative message that these cases present: that demeanour-based credibility assessments are seriously flawed. Instead the Court drew two conclusions from the authorities: ${ }^{73}$

\footnotetext{
${ }^{67}$ At [77].

${ }^{68}$ E (CA113/09) v R (No 3) [2010], above n 35 , at [75]; Albert Vrij Detecting Lies \& Deceit: Pitfalls and opportunities (2nd ed, John Wiley \& Sons, Chichester, 2008) at 124.

${ }^{69}$ At [75]

${ }^{70} E$ (CA113/09) v R (No 3) [2010], above $\mathrm{n} 35$, at [75].

${ }^{71} E(C A 799 / 2012) v R$, above n 5, at [32]; Sateki $v R$ [2011] NZCA 239 at [28].

${ }^{72} E(C A 799 / 2012) \vee R$, above n 5, at [32]; $S(C A 749 / 2012) \vee R$ [2013] NZCA 350 at [27].

${ }^{73} E(C A 799 / 2012) \cup R$ [2013], above n 5, at [34].
} 
First, the risk is not so much placing reliance on demeanour evidence per se. Rather, the real risk arises through considering demeanour evidence in isolation from other evidence and relevant factors.

Second that assessing credibility is closely linked to reliability and where both are at issue they should be approached in a similar way.

Putting the second point aside, the first statement does not seem to follow from the authorities. Among the cases it cited, only Attorney-General of Hong Kong $v$ Wong expressly makes a similar point about assessing credibility from demeanour in isolation. ${ }^{74}$ The only other statement to the effect that demeanour should not be viewed in isolation, comes from the Court itself when it commented on a very brief citation from Sateki. ${ }^{75}$ As such, there does not seem to be a strong basis from case authority to support this conclusion.

Furthermore, the Court has not correctly framed the problem. As jury research has shown, juries generally do not consider demeanour as the sole determinant of credibility. ${ }^{76}$ The real problem does not concern jurors using demeanour in isolation, the real problem is concerned with jurors using demeanour at all, even in combination with other indicators, to assess credibility.

In effect the Court has suggested that demeanour should be compared alongside detail and plausibility, which science suggests are generally more reliable indicators than demeanour. ${ }^{77}$ But, as argued in Part II jurors' consideration of demeanour hinders their overall assessment of credibility. The problem with the Court's suggestion arises when jurors evaluate the plausibility of a witness' evidence correctly, but then weigh it against the witness' demeanour. While the witness' plausibility may correctly indicate their degree of credibility, the witness' demeanour has only a one in two chance of giving a correct indication. This is why it is possible, as Genn suggested, for a completely truthful witness to be disbelieved, due to misleading cues from their demeanour. ${ }^{78}$

\footnotetext{
74 At [33]; Attorney-General of Hong Kong $v$ Wong [1987] 1 AC 501 at 510.

${ }^{75} E(C A 799 / 2012) v R$, above $\mathrm{n} 5$, at [32].

${ }^{76}$ Warren Young, Neill Cameron and Yvette Tinsley "Jury Trials in New Zealand: A Survey of Jurors" (October 1999) at 108.

${ }^{77}$ Kapardis, above n 7, at 279.

${ }^{78}$ Genn, above n 18, at 2.
} 
It is true that the Court's conclusions were a progression from the traditional view, that demeanour is useful in assessing credibility. ${ }^{79}$ However, given the clear message that comes from both the social science research and case authorities, those conclusions do not acknowledge the degree of the problem. Rather, what the Court should have said is that demeanour is an unreliable indicator, when compared to plausibility and consistency, and these criteria should be considered first in a credibility assessment, instead of demeanour. If demeanour is to be used in such assessments at all, the jury should be informed about its unreliability, so that it does not offset those other indicators and lead jurors to incorrectly evaluate a witness' credibility. The logical corollary of this, to be discussed in Part IV, is that since a problem has been identified the Court should have acknowledged the best methods for remedying it.

\section{B The Court's arguments against a Demeanour warning}

As discussed above, neither research nor case authorities appear to support the Court's minimalistic view of the risks posed by demeanour-based credibility assessments. Even if the Court had been correct about these risks, the justifications it provides for a warning being unnecessary are questionable. To support its position the Court relied on arguments raised in Stanley $v R$, as well as that case itself standing for a general proposition that demeanour warnings are not always required.

Stanley can be immediately contrasted with the majority of cases cited above, in particular Fox, Munro, E (CA113/09) vR, $S \vee R$ and Sateki. These cases all highlighted the wellestablished dangers of assessing credibility from demeanour. As such, it seems reasonable to argue that they weigh in favour of a required demeanour warning. The approach of the Court of Appeal in Stanley was similar to that of the Court in $E v R$, in that it downplayed the unreliability of demeanour indicators. ${ }^{80}$ In Stanley, despite the District Court Judge's implicit invitation to the jury to take note of the complainant's demeanour, the Court of Appeal found that a demeanour warning was unnecessary. ${ }^{81}$

The Court, in $E v R$, appears to adopt the view that since a warning was not required in Stanley, one cannot be invariably required. This does not seem justifiable. Assuming

\footnotetext{
${ }^{79} E(C A 799 / 2012) v R$, above $\mathrm{n}$, at [44-45].

${ }^{80}$ Stanley $\vee R$ [2012], above $\mathrm{n} 8$, at [19].

${ }^{81}$ At [19].
} 
Stanley, and the subsequent appeal were correctly decided, they still do not lay down any general proposition regarding demeanour warnings. Stanley dealt specifically with the question of demeanour warnings within the context of its particular circumstances. ${ }^{82}$ That Court expressly declined to make any general comment on the subject of demeanour warnings. ${ }^{83}$ Also, despite the Court in $E v R$ 's reference to it, the Supreme Court's subsequent denial of leave is also unhelpful, as it provided very little insight into its reasoning process. The only clear message provided by the Supreme Court was that judicial directions should be case-specific. ${ }^{84}$ Given that it does not provide much substantive reasoning or discussion in respect of demeanour warnings, Stanley actually seems more ambivalent concerning any general requirement, rather than opposing one as the Court in $E v R$ suggested.

The Court of Appeal in both Stanley and $E v R$, observed that the Evidence Act 2006 is silent on demeanour warnings. ${ }^{85}$ I submit that despite the Act not expressly providing for a mandatory demeanour warning, it would implicitly would support such an instruction. Among the purposes of the Act is the provision for facts for to be established by the application of logical rules. ${ }^{86}$ Employing logic, it would seem that the Act would prefer the fact-finder to use reliable methods of assessing credibility over unreliable ones, such as demeanour. It follows then that warning jurors against using unreliable credibility indicators would enhance the rational ascertainment of facts. The more reliable the credibility assessment of witnesses, the more likely it seems that the fact-finder will arrive at a correct verdict. This approach appears prima facie in line with the Act's purpose, to secure the just determination of proceedings.

Furthermore, the Act provides for directions and warnings in certain circumstances. For example, if a witness gives evidence in an alternative way the judge must direct the jury not to draw an adverse inference against the defendant, because of the manner of giving evidence. ${ }^{87}$ However, it is not an exhaustive source of such instructions. Many directions are found outside the Act. For example, judges are invariably required to direct juries on the

\footnotetext{
${ }^{82}$ At [20].

83 At [20].

${ }^{84}$ Stanley $v R$ SC 77/2012 [2013] NZSC 2 at [3].

${ }^{85} E(C A 799 / 2012) v R$ [2013], above n 5, at [36]; Stanley $v R$ [2012], above n 8, at [20].

${ }^{86}$ Evidence Act 2006, s6(a).

${ }^{87}$ Evidence Act 2006, ss 123,127.
} 
onus of proof. ${ }^{88}$ A key source of judicial warnings, the New Zealand Criminal Jury Trials Bench Book(the Bench Book) was absent from the Court's discussion in $E v R$. The Bench Book is only available for research in limited circumstances but some key insights were generously provided by the Honourable Justice Graham Lang, Chairman of the Bench Book Editing Committee. In particular, the Bench Book does not provide any general demeanour warnings. ${ }^{89}$ However, had the Court mentioned this general silence on demeanour warnings, rather than the Act's, it might have been more persuasive argument against them.

The Courts in both Stanley and $E v R$ also referred to the Law Commission's Report on Evidence Law: Character and Credibility. ${ }^{90}$ The Commission's discussion of the subject began by highlighting the inadequacy of demeanour as a determinant of truthfulness. ${ }^{91}$ The report suggested that cultural differences make demeanour cues even less reliable, as certain cultural norms can easily be misinterpreted. ${ }^{92}$ Nonetheless, the Commission decided that demeanour warnings should be fashioned according to the circumstances of the case rather than be generally required. ${ }^{93}$ It felt that an evidence code would probably be unable to correct for problematic cultural perceptions. ${ }^{94}$ With respect, the Commission identified a legitimate problem and then suggested that nothing be done about it. This appears to leave the law in an unsatisfactory state.

A similar report by the Australian Law Reform Commission(The Australian Commission) also dealt with the problem of misinterpretation of culture-specific demeanour cues. ${ }^{95}$ However, I suggest that since science has shown that these cues are likely to be misread, a court should do its best to remove them from consideration altogether. ${ }^{96}$ If an appropriately-worded warning was given to the jury to disregard all demeanour cues and focus on better indicators of credibility, this would seem to mitigate cultural misunderstandings. Perhaps this is why the Australian Commission made a different

\footnotetext{
${ }^{88}$ Email correspondence with the Honourable Justice Graham Lang, June $11^{\text {th }} 2014$.

${ }^{89}$ Email correspondence with the Honourable Justice Graham Lang, June $11^{\text {th }} 2014$.

${ }^{90}$ Stanley v R [2012], above n 8, at [ 20 ] ; $E(C A 799 / 2012)$ v $R$ [2013], above n 5, at [35]; Law Commission Evidence Law: Character and Credibility, above $\mathrm{n} 8$.

${ }^{91}$ Law Commission Evidence Law: Character and Credibility, above n 8, at [ 117].

${ }^{92}$ At [ 117]-[119].

93 At [119].

${ }^{94}$ At [119].

95 Australian Law Reform Commission Multiculturalism and the Law ( ALRC R57 1992).

${ }^{96}$ Australian Law Reform Commission Multiculturalism and the Law, above n 96, at [10.54]; Zuckerman and Roberts, above n 3, at 300.
} 
recommendation to its New Zealand counterpart, in respect of demeanour warnings, despite having similar concerns. ${ }^{97}$

In summary, neither Stanley, nor the New Zealand Law Commission's recommendations provide persuasive reasons against making demeanour warnings mandatory -whereas the Act's purposes would arguably support such warnings.

\section{Part IV The usefulness of a demeanour warning}

\section{A Research on the efficacy of judicial directions}

Having argued that demeanour should be removed from the assessment of credibility, as much as possible, the focus shifts to how this could be achieved. Courts regularly instruct juries on matters of weight, regarding certain types of evidence, so the idea of a demeanour warning does not seem inappropriate, in principle. Conversely, allowing jurors to make credibility assessments based on demeanour indicators, or to use demeanour alongside other indicators without a warning as to the risks, is to allow an unacceptably high element of chance into an already fraught exercise. A demeanour warning would therefore seem to be in line with the Act's purposes. ${ }^{98}$ It would assist with the rational ascertainment of facts, by encouraging jurors to assess witness' credibility based on more reliable indicia than demeanour.

If questions of potential efficacy were raised, I would submit that such a warning would be well within the capabilities of jurors to follow. Prima facie, asking a jury to merely put aside whatever impressions they may have formed, based on a witness' demeanour, seems a reasonable request. This is corroborated by David Sklansky who suggests that while a jury cannot be asked to forget evidence they have seen, they can effectively set that evidence to one side, when assembling their determination of fact. ${ }^{99}$ Also, Sklansky's research has shown that if juries are given clear reasons why they are to disregard certain types of evidence, rather than an abstract direction, they are more likely to follow them. ${ }^{100}$

\footnotetext{
${ }^{97} E(C A 799 / 2012) v R$, above n 5, at [36] ; Australian Law Reform Commission Multiculturalism and the Law, above $\mathrm{n} 96$, at [10.54].

98 Evidence Act 2006, s6(a).

99 David Sklansky "Evidentiary Instructions and the Jury as Other" (2013) 65 Stanford Law review 407 at 414. 100 At 456.
} 
I submit that a demeanour warning, and the reasons for not relying on demeanour to assess credibility, can be clearly explained. This was even implied by the Court, in $E v R$, when it endorsed the Canadian model jury instruction. ${ }^{101}$ The Canadian warning specifically mentions the relative usefulness of consistency and other factors, compared with demeanour, as indicators of credibility: ${ }^{102}$

What was the witness's manner when he or she testified? Do not jump to conclusions, however, based entirely on how a witness has testified. Looks can be deceiving. Giving evidence in a trial is not a common experience for many witnesses. People react and appear differently. Witnesses come from different backgrounds. They have different abilities, values and life experiences. There are simply too many variables to make the manner in which a witness testifies the only or most important factor in your decision."

As one author described it, this warning is permeated with cautions about the unreliability of demeanour evidence. ${ }^{103}$ Although I differ from the Court of Appeal about the frequency with which such a warning should be given, I concur that this model could serve well in the New Zealand context. Following Sklansky's suggestions about clear reasons, perhaps it could be accompanied by a brief and simple statement about current state of research: that demeanour-based credibility assessments generally operate with 50 per cent accuracy. This does not seem to be an overly complicated message for jurors to comprehend.

Social science research also supports the idea that clearly instructed jurors may make better credibility assessments. Open-minded questioners, who do not jump to conclusions too quickly, can become aware of the difficulties of correctly identifying a truthful, but nervous, witness. 104 Jurors, who are made aware of the weaknesses in demeanour-based credibility assessments, would therefore seem more likely to make accurate credibility deductions. Also, while Coyle did not go so far as to recommend an express judicial direction on the subject of demeanour and credibility he did recommend that the flawed judicial directions be

${ }^{101} E(C A 799 / 2012) \vee R[2013]$, above n 5, at [48].

${ }^{102}$ Canadian Judicial Council, "Model Jury Instructions: 9.4 Assessment of Evidence" (June 2012) National Judicial Institute- Institute National de la Magistrature <https://www.nji-inm.ca/nji/inm/progs-res/juryinstructions-les-directives-au-jury.cfm?lang=en.>

${ }^{103}$ Bakht, above n 50, at 600; Canadian Judicial Council "Model Jury Instructions: 9.4 Assessment of Evidence", above n 97.

${ }^{104}$ Genn, above n 18 , at 5 . 
corrected. ${ }^{105}$ He suggested that having expert evidence on the subject of demeanour, as well as judicial directions based on scientific fact, would vastly improve a jury's ability to properly distinguish truthfulness from deception. ${ }^{106}$ This is certainly a step further than the Court, in $E v R$, was prepared to go.

Furthermore, research clearly shows that some jury directions are better adhered to than others. ${ }^{107}$ For example, a New Zealand jury study revealed that jurors often followed the direction not to draw inferences from a defendant who did not give evidence. ${ }^{108}$ However, the direction regarding inferences from proved facts was often misunderstood. ${ }^{109}$ The reason for this disparity is that certain directions require jurors to make distinctions which are extremely subtle or counter-intuitive. ${ }^{110}$ I submit that a demeanour warning would be less difficult for a jury to follow than some judicial directions that are currently in use.

An example of a particularly complex contemporary judicial direction is the Woodhouse direction. This instruction requires a jury not to infer that a defendant who elects not to give evidence is guilty, but at the same time allows them to weigh that silence against accepting some or all of the defence's submissions. ${ }^{111}$ This distinction has been described as "fine at best" and whether it exists at all has been questioned. ${ }^{112}$ Courts have also acknowledged that the jury is likely to make assumptions based on the election not to testify, whether a judicial warning is given or not. ${ }^{113}$ Regardless when the Woodhouse direction is given, the expectation is still that a jury will follow it.

In contrast, a demeanour warning similar to the Canadian model would demand far less of jurors. Essentially, it would simply ask the jury to put one type of evidence aside, something Sklansky has argued they are already capable of doing. Clearly, if Courts can expect juries to follow directions as conceptually challenging as Woodhouse, they should be able to expect them to follow a demeanour warning.

\footnotetext{
105 Coyle, above n 42 , at 26.

106 Coyle, above n 42, at 26.

107 Warren Young, Neill Cameron and Yvette Tinsley, above n 74, at 223.

108 At 229.

109 At 229.

110 At 226.

$111 R v$ Woodhouse CA 117/06, 12 October 2006 at [16].

112 Don Mathieson(ed) Cross on Evidence ( $9^{\text {th }}$ ed, LexisNexis NZ ltd, Wellington, 2013) at 172.

113 At 172.
} 


\section{B Judicial discretion as to the importance of demeanour in a case}

Another potentially beneficial aspect of a required demeanour warning would be its ability to reduce the possibility for appealable errors, by removing judicial discretion. Currently, with no express guidance from the Bench Book, it is for the judge to determine if demeanour is in issue and give whatever warning that he or she feels is necessary. If the judge is incorrect, as to whether demeanour was in issue, and fails to give a warning the case might be overturned on appeal. ${ }^{114}$ This discretion is based on the assumption that a judge will actually know if demeanour is in issue or not, with respect to credibility. I submit that, in the light of the research discussed earlier in this paper, this assumption is not sound.

For this assumption to be correct the judge would have to accurately determine that the witness' demeanour may influence the jury's credibility assessment. This requires the judge to be able to accurately conduct both their own assessment of the witness' demeanour and then accurately predict what use the jury will make of it. However, expertise in reading micro-expressions is not part of standard legal training and research has shown that judges and lawyers are generally subject to the same margin of error as laypeople when using demeanour to assess credibility. ${ }^{115}$ This is compounded by Zuckerman and Roberts' “double whammy", that not only will a judge's accurate assessment of demeanour be at chance level, but also that they will likely be completely incorrect about their own competence to make that assessment. ${ }^{116}$ As such, there does not seem to be any principled basis on which to make the original assumption, and I submit that judicial discretion in this regard is part of the problem.

In contrast, the Court, in $E v R$, expressed concern that a required direction would restrict judicial discretion in tailoring case-specific warnings. ${ }^{117}$ Its view was that the judge should be unfettered, to craft a warning that would reflect demeanour's relative importance in the case. ${ }^{118}$ Here the Court was clearly relying on the aforementioned questionable assumption. The Bench Book and the Court in Stanley also suggest that the Judge should consider whether counsel raised demeanour as an issue, when deciding whether to give a demeanour

\footnotetext{
114 See $S(C A 749 / 2012) v R$ [2013] NZCA 350.

115 Bakht, above $\mathrm{n}$ 50, at 598.

116 Zuckerman and Roberts, above n 3, at 300.

${ }^{117} E(C A 799 / 2012)$ v $R$ [2013], above n 5, at [46].

${ }^{118} E(C A 799 / 2012) v R$ [2013], above n 5, at [46].
} 
warning. ${ }^{119}$ I argue that this should not be a definitive indicator because counsel are similarly susceptible to error when assessing demeanour's relation to credibility. As submitted in Part II, the better approach is to assume that demeanour is almost always in issue to some degree, unless perhaps the witness testifies in an alternative way. A mandatory demeanour warning would address the problem by removing judicial discretion, and the possibility for error that it presents.

\section{General arguments against a demeanour warning}

Having argued the merits of a mandatory demeanour warning I must now address some of the key arguments against one. The primary argument against a general demeanour warning is that of misinterpretation. The potential for a demeanour warning to be misinterpreted by the jury has been asserted by the Court of Appeal in $E v R$, the Australian Law Reform Commission, and the Minister of Justice. ${ }^{120}$ Anecdotally, when I informally discussed this paper's premise with several legal academics the misinterpretation argument was the first raised. ${ }^{121}$

The Court argued that a demeanour warning might be an invitation to the jury to disbelieve a witness or place diminished weight on their evidence. ${ }^{122}$ Similarly, the Minister suggested that a jury may believe they are being "given a clue" by the judge and draw an incorrect inference. ${ }^{123}$ The Commission suggested that by giving a demeanour warning a judge may create doubt in the jury's mind as to whether they have actually determined a witness' truthfulness. ${ }^{124}$ They also raised the concern that such a warning may actually emphasise demeanour as a credibility-assessing tool. ${ }^{125}$ It should be noted that despite these reservations, the Australian Law Reform Commission still recommended that courts should become more aware of the desirability of demeanour warnings. ${ }^{126}$ Perhaps this indicates the Commission felt that demeanour-based credibility assessments pose a greater threat to the

\footnotetext{
${ }^{119}$ Email correspondence with the Honourable Justice Graham Lang, June 11 ${ }^{\text {th }}$ 2014; Stanley $v$ R [2012] NZCA 462.

${ }^{120} E$ (CA799/2012) v R [2013], above n 5, at [41]; Judith Collins, above n 30, at [43-46]. Australian Law Reform Commission Multiculturalism and the Law, above n 96, at [10.62].

${ }^{121}$ Discussed with Professor ATH Smith, Associate Professor Elisabeth McDonald, Dr. Yvette Tinsley, and Senior Lecturer Mamari Stephens, (VUW Law School Honours programme symposium, June $5^{\text {th }}, 2014$ ).

${ }^{122} E(C A 799 / 2012) \vee R$ [2013], above n 5, at [41].

123 Judith Collins, above n 30, at [43-46].

${ }^{124}$ Australian Law Reform Commission Multiculturalism and the Law, above n 96, at [10.62].

125 At [10.62].

${ }^{126}$ Australian Law Reform Commission Multiculturalism and the Law, above n 96, [10.62].
} 
just determination of proceedings than the untested risks that the Court of Appeal asserted in $E v R$

Although the risk of misinterpretation sounds like a legitimate argument against making a demeanour warning mandatory, it is highly questionable for two reasons. First, evidence shows that all jury warnings and directions are intrinsically flawed. ${ }^{127}$ Every warning carries a risk of misinterpretation. ${ }^{128}$ This was discussed by Sklansky, who asserted that before the actual efficacy of judicial directions could be investigated their inherent imperfection must be acknowledged. ${ }^{129}$ Sklansky suggested that underlying reason for their shortcomings lies within the imperfect nature of juries themselves. ${ }^{130}$ This is not difficult to accept. Essentially, a jury is a group of strangers who are asked to effectively assess the probative credibility of other strangers.

Sklansky's comments are made in the American context, but are generally supported by insights revealed by a New Zealand jury study. ${ }^{131}$ The study revealed that an overwhelming number of jurors found the judge's summary of facts useful, but a majority ( 35 out of the 48 trials surveyed) still fundamentally misunderstood aspects of the law they were asked to apply. ${ }^{132}$ These misunderstandings, which influenced the decision-making process, ranged from the ingredients of the offence to the standard of proof. ${ }^{133}$ Such errors indicate that it is unrealistic to expect juries to perfectly follow judicial directions. However, this is no reason against making directions in general, otherwise no judicial direction should ever be made. Sklansky's research shows that although directions may be followed imperfectly, they do still work. ${ }^{134}$ As such, the risk of misinterpretation is not a persuasive argument against making a demeanour warning required.

Secondly, the suggestion that a demeanour warning may cause the jury to think the judge is indicating their personal view is unpersuasive because, as New Zealand jury research has revealed, juries routinely do this anyway. ${ }^{135}$ The study found that in the majority of cases there was a strong correlation between the jurors' perception of the judge's view and their

\footnotetext{
127 Sklansky, above n 99, at 409.

128 At 409.

129 At 419.

130 At 417.

${ }^{131}$ Warren Young, Neill Cameron and Yvette Tinsley, above n 74, at 222.

132 At 213.

133 At 213.

${ }^{134}$ Sklansky, above n 99, at 439.

135 Warren Young, Neill Cameron and Yvette Tinsley, above n 74, at 222-4.
} 
own view, although there was no correlation between that perception and the actual view of the judge. ${ }^{136}$ Thus, a demeanour warning would likely be incidental to the jury trying to work out the judge's view, rather than causative of it. As such, this is not a persuasive argument against a mandatory demeanour warning.

It has also been suggested, by the Court in $E v R$, that a demeanour warning is actually unnecessary. ${ }^{137}$ This was argued on the basis that jurors, in the New Zealand jury study, reported using a balanced assessment of the evidence as a whole to determine truthfulness. ${ }^{138}$ However, the study's authors were more cautious than the Court in evaluating jurors' ability in this regard. They stated that, "juries as a whole appeared to weigh up the reliability of testimony in the light of other evidence." 139 The use of appeared perhaps suggests an implicit acknowledgement that this information was collected on the basis of self-reporting. Thus, it is not possible to conclusively say that even those jurors who claim to have conducted such a balanced credibility inquiry were not influenced in some part by the witness' demeanour. Furthermore, in a minority of cases jurors actually admitted that their impression of witnesses did influence their perceptions of their credibility. ${ }^{140}$ This gave rise to three questionable acquittals. ${ }^{141}$ As such, while the study revealed other useful information about how judicial directions are received, it does not provide authoritative support for the Court of Appeal's assertion.

In the light of contemporary research the arguments against a required demeanour warning are unpersuasive. Thus, I submit that a properly-explained demeanour warning would be a useful addition to every judge's summation to the jury.

\footnotetext{
136 At 222.

${ }^{137} E(C A 799 / 2012) v R$ [2013], above n 5, at [39].

${ }^{138}$ Warren Young, Neill Cameron and Yvette Tinsley, above n 74, at 109.

139 At 109.

140 At 109.

141 At 109.
} 


\section{Conclusions}

Demeanour was once thought of as a useful tool for assessing the credibility of witnesses. However the commonly held belief, that people can detect lies from demeanour indicators alone, has been shown to be a popular misconception. Social science has demonstrated that most people have, at best, a fifty per cent chance of accurately using demeanour to spot deception. At the same time they are usually completely oblivious to this problem. As such, demeanour is an unreliable tool for assessing a witness' credibility.

Unfortunately, this scientific understanding of demeanour evidence is not fully reflected in courtroom practice. In $E v R$, the Court of Appeal had a chance to bring the law into step with science, by making a demeanour warning mandatory in criminal jury trials. Instead the Court took an overly conservative approach, in which it suggested that demeanour could still be part of witness credibility assessments. This approach was a development on previous practice, in which judges actively encouraged juries to observe demeanour to assess credibility. However it still lags behind science, in terms of recognising the truth about the flawed nature of such assessments.

I have argued that a demeanour warning should be mandatory in all criminal jury trials. This position is supported by both social science and case authorities, including those authorities cited in $E v R$. A demeanour warning would benefit the trial process by raising jurors' awareness of the risks involved in demeanour-based credibility assessments. It would enhance the rational ascertainment of facts by requiring jurors to assess credibility using much more reliable indicia, than demeanour. Furthermore, jury research suggests that a demeanour warning may be received at least as well as, if not better than, other current judicial directions. Such a warning would have far less potential to be misconstrued, than some of the complex and counter-intuitive directions that are currently in use.

The Court's arguments, in respect of a demeanour warning's potential to confuse jurors, are countered by the simple truth that all judicial warnings and directions are inherently imperfect and carry a risk of misinterpretation. That risk could be further ameliorated by a well-worded warning such as the Canadian model, which was endorsed by the Court in $E v R$. Although it is true that a demeanour warning would always risk being misinterpreted by the jury, I submit that the greater risk to just determinations of proceedings is posed by jurors making demeanour-based credibility assessments. As Sklansky surmised, while jury 
directions might be imperfect, a much greater evil would be to allow verdicts to be influenced by prohibited evidence or forbidden inferences. ${ }^{142}$

In deciding to keep demeanour, as part of the overall witness credibility assessment, the Court of Appeal showed a desire to cling to the face value of witness testimony. This paper has suggested that the Court's fascination with demeanour, as a means of assessing credibility, seems to be shared by other influential lawmakers. In order to improve the accuracy of criminal jury proceedings it is hoped that both jurists and parliamentarians can look past the allure of demeanour and adopt a mandatory demeanour warning. This approach would be supported by contemporary science, and is preferable to continuing to allow credibility assessments to be made using a process which bears the same margin of error as a coin toss.

142 Sklansky, above n 99, 456. 


\section{BIBLIOGRAPHY}

\section{CASES}

$E(C A 799 / 2012) v R$ [2013] NZCA 678.

$E(C A 113 / 09) v R$ (No 3) [2010] NZCA 544.

Fox v Percy (2003) 214 CLR 118.

Police v Razamjoo [2005] DCR 408.

$R$ v Munro [2007] NZCA 510.

$R v$ Woodhouse CA 117/06, 12 October 2006.

S (CA749/2012) v R [2013] NZCA 350.

Sateki $v R$ [2011] NZCA 239.

Stanley $v$ R [2012] NZCA 462.

Stanley $v R$ SC 77/2012 [2013] NZSC 2 at [3].

Attorney-General of Hong Kong v Wong [1987] 1 AC 501.

\section{STATUTES AND PARLIAMENTARY MATERIALS}

Courts (Remote Participation) Act 2010.

Evidence Act 2006.

New Zealand Bill of Rights Act 1990.

Judith Collins "Amendments to the Evidence Act 2006" (12 November 2013) CAB $100 / 2008 / 1$. 


\section{BOOKS}

Adrian Zuckerman and Paul Roberts Criminal Evidence ( $2^{\text {nd }}$ Ed, Oxford University Press, Oxford, 2010).

Albert Vrij Detecting Lies \& Deceit: Pitfalls and opportunities (2nd ed, John Wiley \& Sons, Chichester, 2008) at 124.

Andreas Kapardis Psychology and Law a Critical Introduction $\left(3^{\text {rd }}\right.$ Ed, Cambridge University Press, Melbourne).

Catherine Soanes Angus Stevenson (eds) Oxford Concise English Dictionary ( $11^{\text {th }}$ Ed, Oxford University Press, New York, 2008).

Don Mathieson (ed) Cross on Evidence ( $9^{\text {th }}$ ed, LexisNexis NZ ltd, Wellington, 2013).

Elisabeth McDonald Principles of Evidence in Criminal Cases ( Brookers, Wellington, 2012).

Patrick Devlin The Judge (Oxford University Press, Oxford, 1979).

Paul Ekman Telling Lies (Berkley Books, New York, 1986).

Richard Mahoney, Elisabeth McDonald, Scott Optican and Yvette Tinsley The Evidence Act 2006 Act and Analysis ( $3^{\text {rd }}$ ed, Brookers, Wellington, 2014).

\section{ESSAYS IN BOOKS}

Lord Bingham “Assessing Contentious Eyewitness Evidence: Judicial View” in Anthony Heaton-Armstrong and others (eds) Witness Testimony, Psychological, Investigative and Evidential Perspectives (Oxford University Press, Oxford, 2006) .

Natasha Bakht What's in a Face ? "Demeanour Evidence in the Sexual Assault Context" in Elisabeth A. Sheehy (ed) Sexual Assault in Canada (University of Ottawa Press, 2012). 


\section{JOURNAL ARTICLES}

Aldert Vrij, Par Anders Granhag, Samantha Mann and Sharon Leal, "Outsmarting the Liars: Toward a Cognitive Lie Detection Approach" (2011) Current Directions in Psychological Science 20 (1).

Aldert Vrij, Par Anders Granhag, Stephen Porter “ Pitfalls and Opportunities in Nonverbal and Verbal Lie Detection" (2010) Psychological Studies in the Public Interest 000(00).

Brian MacKenna “Discretion” (1974) IX (new series) The Irish Jurist.

David Sklansky "Evidentiary Instructions and the Jury as Other" (2013) 65 Stanford Law review.

Elisabeth McDonald and Yvette Tinsley "Use of Alternative Ways of Giving Evidence by Vulnerable Witnesses: Current Proposals, Issues and Challenge" 42 VUWLR 705.

Hazel Genn “Assessing Credibility” (2011) 11 Tribunals Journal.

Marcus Stone "Instant lie detection? Demeanour and credibility in criminal trials" Crim. L.R. 1991.

Olin Guy Wellborn “Demeanour” (1991) 76 Cornell L Rev 1075.

\section{WEBSITES}

Canadian Judicial Council, "Model Jury Instructions: 9.4 Assessment of Evidence" (June 2012) National Judicial Institute- Institute National de la Magistrature < https://www.njiinm.ca/nji/inm/progs-res/jury-instructions-les-directives-au-jury.cfm?lang=en>

\section{REPORTS}

Australian Law Reform Commission Multiculturalism and the Law (ALRC R57 1992).

New Zealand Law Commission Evidence Law: Character and Credibility (NZLC PP 27, 1997). 
Warren Young, Neill Cameron and Yvette Tinsley "Jury Trials in New Zealand: A Survey of Jurors" (October 1999).

\section{PAPERS PRESENTED AT CONFERENCES}

Ian R Coyle “ How Do Decision Makers Decide When Witnesses Are Telling The Truth And What Can Be Done To Improve Their Accuracy In Making Assessments Of Witness Credibility?" ( Report to The Criminal Lawyers Association of Australia and New Zealand, 3 April 2013).

Robert Fisher "Can we tell when people are lying ? " (Paper presented to AMINZ conference, Auckland, 25 July 2013).

\section{SPEECHES}

Greg King, "Debate over the right to silence" ("Justice Hot Tub", Victoria University School of Law, Wellington, 20 July 2012).

\section{OTHER}

Email correspondence with the Honourable Justice Graham Lang, June $11^{\text {th }} 2014$.

\section{Word count}

The text of this paper (excluding table of contents, footnotes, and bibliography) comprises approximately 7,973 words + substantive footnote $121(26$ words $)=7,999$ words 